\title{
Recognition and Redistribution: Finding Common Ground between Two Conceptions of Freedom
}

\begin{abstract}
Michael E. Snyder*
One of Axel Honneth's central claims is that scholars too often draft their moral-political theories without sufficient treatment of the role played by intersubjectively developed social norms. This recognition approach to freedom, however, is often criticized for its subordination of redistributive justice claims to feelings of disrespect. In this article, I defend Honneth's general claims by explicating how specific policies for distributive justice can be closely imbricated, even mutually reinforcing, with Honneth's broader criteria of justification through mutually recognized social norms. I use Martha Nussbaum's conception of freedom as capability and Philip Pettit's theory of freedom as non-domination as two examples for how recognition and distributive justice are closely linked. [Article copies available for a fee from The Transformative Studies Institute. E-mail address:_ journal@transformativestudies.org_Website:
\end{abstract} http://www.transformativestudies.org (C2017 by The Transformative Studies Institute. All rights reserved.]

KEYWORDS: Honneth, Recognition, Non-Domination, Capabilities, Redistribution, Freedom, Justice.

\footnotetext{
* Michael E. Snyder received his Ph.D. in Political Theory from Queen's University Belfast's department of Politics, International Studies, and Philosophy in the summer of 2016. Dr. Snyder has published a book review in the International Journal of Philosophical Studies as well as coauthored an article in The Book of the States, and has presented his research at workshops at the University of Illinois Springfield, Queen's University Belfast, and the Midwest Political Science Association's annual conference. Dr. Snyder's research interests include critical theory, recognition theory, and distributive justice. Address correspondence to: Michael Edward Snyder, Queen's University Belfast; e-mail: msnyder02@qub.ac.uk.
}

Acknowledgments: I would like to thank Dr. Cillian McBride, Dr. Simon Thompson, and Dr. David Archard for their contributions and invaluable input in developing this article. I would also like to thank Dr. Richard Gilman-Opalsky for his input, and for helping to arrange for me to present my work at a workshop at the University of Illinois Springfield in 2014. I would also like to thank all of the panel discussants who gave constructive criticism and insight at the 2015 MPSA Annual Conference. Without the help of these individuals, and many others, this work would not have been possible. All errors are my own. 